Lyudmila NEKHOROSHEVA*, Anna ABUSHIK**, Tatyana MODZALEVSKAYA** and Dmitry PATRUNOV*

\title{
THE EVENTS AT THE WENLOCK-LUDLOW BOUNDARY IN PALEOBASINS OF THE URAL-NOVAYA ZEMLYA AREA
}

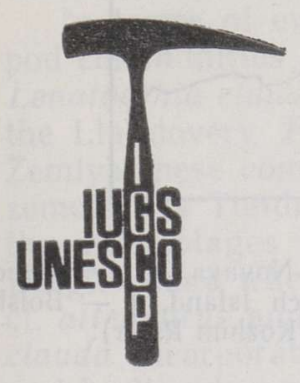

GLOBAL BIOEVENTS

The Wenlock-Ludlow boundary is of interest as it separates two major stages in the development of the Silurian paleobasins. The first stage embraces the maximum transgression (Llandoverian) and is marked by a wide distribution of shallow-water and stagnant quiet water facies and by the occurrence of diverse benthic and pelagic (graptolite) fauna. The second stage shows in general a regressive tendency in the development of paleobasins; as compared to the early Silurian stage, the faunal provincialism is more evident here.

The peculiar features of the two stages in the Silurian sedimentation are discussed here on the data from the Ural-Novaya Zemlya area where shallow-water marine mainly carbonate Silurian deposits are wide-spread. Within the area (Fig. 1) the late Wenlock-early Ludlow succession was studied in the southern Novaya Zemlya (Обьяснительная ..., 1981; Объяснительная ..., 1983), Dolgii Island (Силурийские ..., 1980), Polar Urals (Опорные ..., 1987; Першина et al., 1971), and Bolshezemelskaya Tundra (Антошкина, Безносова, 1988; Модзалевская, 1980).

These sections are characterized by the absence of breaks, occurrence of mainly carbonate deposits exhibiting easily discernible characters of extremely shallow waters and fairly uniform benthic fauna. Because of such a character of the deposits the Wenlock-Ludlow boundary can be determined in the sections only tentatively.

In southern Novaya Zemlya the Wenlock-Ludlow interval was studied in a continuous and well exposed succession (Fig. 2). Both the upper Wenlock (Middle Klenova Member, 250-300 $\mathrm{m}$ thick) and lower Ludlow (Upper Klenova Member, $185 \mathrm{~m}$ thick) rocks are of extremely shallow water origin. The Middle Klenova Member is dominated by pelletoidal wackestone interbedded with algal layered limestones, early diagenetic dolomites, thin Parastriatopora-Striatopora biostromes, ostracode limestones and scarce lenticular brachiopod coquina. The upper part of the Member yields stromatolites. The Upper Klenova Member is also dominated by different pelletoidal wackestones. However, unlike the underlying unit, here the amount of algal limestones gradually decreases up the section, stromatolites disappear, and the amount of granular-silty limestones as well as the diversity of benthic assemblages increase.

\footnotetext{
* ВНИИ океангеологии (All-Union Scientific Research Institute of Ocean Geology), 190121 Ленинград, Мойка 120.

** ВСЕГЕИ (All-Union Geological Scientific Research Institute), 199026 Ленинград, Средний пр. 74.
} 


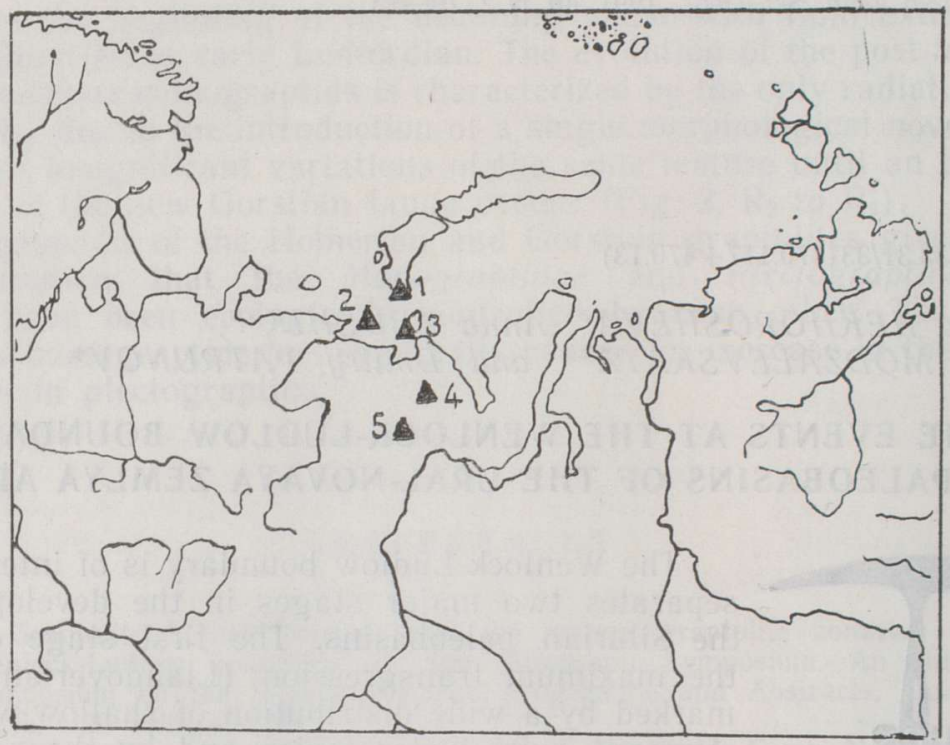

Fig. 1. The key sections of the carbonate Silurian in the Ural-Novaya Zemlya region. 1 - Southern Novaya Zemlya, 2 - Dolgii Island, 3 - Vaigach Island, 4 - Bolshezemelskaya Tundra (Chernov Uplift), 5 - Polar Urals (Kozhim River).
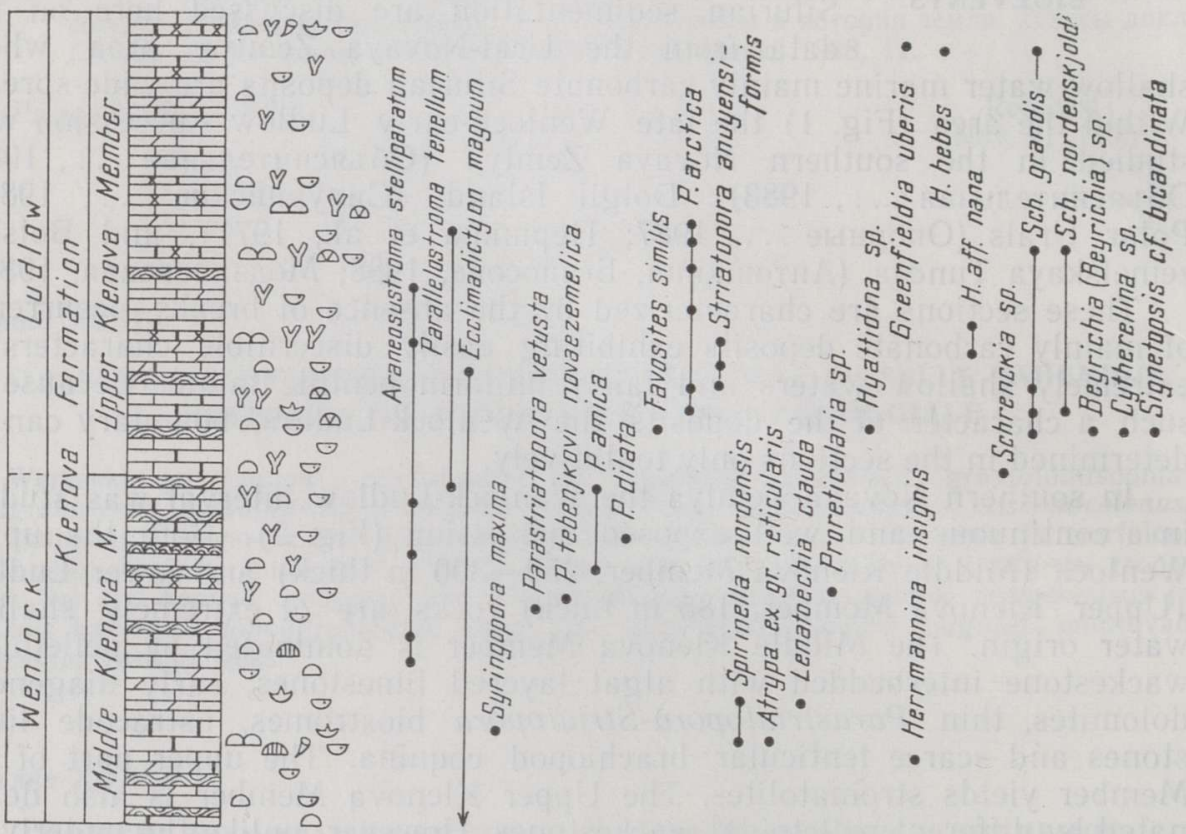

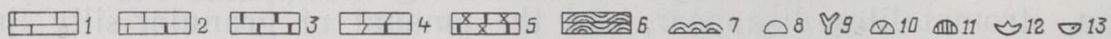

Fig. 2. Stratotype of the Middle and Upper Klenova formations at the Khatanzeya Peninsula (Southern Novaya Zemlya). 1 - ostracode micritic limestone, 2 - biomicrite or wackestone, 3 - packstone or grainstone, 4-dolomitic limestone, 5 - coralstromatoporoid biostrome, 6 - pelletoidal algal limestone, 7 - stromatolite, 8 - Stromatoporata, 9-11 - Tabulata: 9- Parastriatopora, Striatopora, 10 - Favosites, 11 - Syringopora, 12 - Brachiopoda, 13 - Ostracoda. 
The boundary between the Middle and Upper Klenova Members is tentatively accepted by authors as the Wenlock-Ludlow boundary. At this tentative boundary no drastic changes took place either in lithology or in the faunal succession. The grounds used to draw this boundary are as follows.

Benthic associations and communities reported from the upper Middle Klenova and lower Upper Klenova members exhibit a very poor diversity, being often monotaxic. For example, a very common stromatoporate community (Araneosustroma stelliparatum, Parallelostroma tenellum) traces the accepted boundary. Among tabulate corals represented mainly by the genus Parastriatopora a gradual change in the species composition takes place in the boundary beds. As to brachiopods, the Spirinella nordensis community disappears near the boundary and a typical early Ludlow Greenfieldia assemblage appears above this boundary.

In terms of evolution the appearance of the Middle Klenova brachiopod communities including Spirinella nordensis, Atrypa ex gr. reticularis, Lenatoechia clauda (occurring in sections as pairs) is quite separate from the Llandovery Pentamerus oblongus community. Apart from Novaya Zemlya these communities were recorded from Dolgii Island and Bolshezemelskaya Tundra on the Chernov Uplift. The taxonomic composition of the assemblages varies slightly across the area. It is most complete on Dolgii Island where the above species occur together with Morinorhynchus cf. attenuatus and Hyattidina sp., their biozones like those of Lenatoechia clauda incorporate a much wider stratigraphic range than the Wenlock and Ludlow boundary beds discussed. As these communities have no exact precursors in the Ural-Novaya Zemlya basins, they can be considered as immigrants. They are represented mainly by small shells with articulated valves occurring in wackestone bands. Very common are slowly evolving cosmopolitan genera such as Atrypa. In these communities there are no key genera. According to A. Boucot (Буко, 1979) they can be considered as benthic assemblage 3 belonging to the Striispirifer community group. The studied communities dwelt in quiet shallow water, taxonomically they were not diverse due to abnormal environmental factors suppressing the development and distribution of taxa among which only the most tolerant species survived.

The appearance of the Greenfieldia uberis community (with rare Proreticularia sp.) in the Upper Klenova Member was caused by the evolution of athyridids as well as by immigration and wide distribution of the earlier unknown taxa in the Ural-Novaya Zemlya area. On Dolgii Island Atrypella and Conchidium novosemelicum communities appear concurrently with Greenfieldia. The populations of the communities were, as a rule, large, their composition varied, though in general they were uniform and represented by a few taxa. The poorest communities have been reported from the Polar Urals and Bolshezemelskaya Tundra. The collections are usually represented by complete valves with extreme forms of variability suggesting a polytypical structure of some species. Spirai brachiopods occur in the form of articulated valves and are related to wackestone. According to A. Boucot (Буко, 1979) these communities can be assigned to the benthic assemblage 2 related to quiet shallow waters. Patchy distribution of brachiopods across the area and their relative monotony seem to have been controlled by the distribution of sediments and algal mats.

Thus, based on brachiopods, the Middle and Late Klenova time was in the development of the Southern Novaya Zemlya basin, like in other basins of the Ural-Novaya Zemlya area, a period of a low taxonomic diversity of fossils. This was caused by stable but not quite normal environmental conditions. According to an indirect correlation this time interval 
corresponds to the Wenlock-Ludlow boundary of the standard. This is confirmed by the appearance of representatives of the genus Proreticularia reported as yet only from Ludlow. The taxonomic composition of the above brachiopod communities is very peculiar, being typical only of the communities of the northeastern European province. A certain tendency in the evolution of athyridids can be traced also in the north- and southwestern parts of the province. So, an athyroid lineage represented by the genus Greenfieldia typical of the Ural-Novaya Zemlya basins appears at the Wenlock-Ludlow boundary. Later, during the Late Silurian-Early Devonian, under conditions favourable for athyridid evolution, their generic composition gradually changed: Greenfieldia $\rightarrow$ Didymothyris $\rightarrow$ Collarothyris $\rightarrow$ Protathyris.

The ostracode communities at the Wenlock-Ludlow boundary in the study area are characterized by the morphological continuity enabling to distinguish a leap in their evolution, i. e. the appearance of an evolutionary-progressive feature in the leading groups such as leperditicopids, beyrichiocopids, kloedenellocopids and primitiopsicopines which become diverse in the Late Silurian time. For example, the appearance of true Leperditia, highly organized Schrenckia, Bispinitia, Kiaeria among leper diticopids; structurally more complex and diverse beyrichiocopids (presence of Beyrichia, Altibeyrichia, Simplicibeyrichia, a. o.), more highly organized kloedenellocopids (Eoevlanella, Kloedenella) and primitiopsicopines (Scipionis, Signetopsis, a. o.).

The same change pattern of the ostracode associations at the WenlockLudlow boundary is traceable throughout the entire Novaya Zemlyawestern Ural area (Polar and North Urals, Chernyshev Ridge, Chernov Uplift, Dolgii Island, southern Novaya Zemlya) and also on the north western Siberian Platform, and Severnaya Zemlya (Абушик, 1989).

Discussing the fauna as a whole we can say that of the various benthic groups 11 genera reach the accepted boundary, three genera cross it, and eight appear on different levels above the boundary in the succession in southern Novaya Zemlya (Fig. 3). A similar pattern of the change in the composition of benthic communities at the Wenlock-Ludlow boundary has been recorded in the sections of the whole represented area.

A lithological analysis at the Wenlock-Ludlow boundary based on the southern Novaya Zemlya section and other similar sections of the UralNovaya Zemlya area shows this section to be fairly monotonous and represented by shallow water sediments. This implies that sedimentary conditions in the basins discussed did not change considerably during the late Wenlock-early Ludlow. D. K. Patrunov is of the opinion that only an unimportant "sudden change" in the facies sequence is observed at the accepted Wenlock-Ludlow boundary. At this level shallow water sedimentary conditions similar to those of the littoral area started to change towards more intense marine hydrodynamics. From there increases also the rock-forming role of fauna. This is evidenced by the appearance of local growth of Parastriatopora and Striatopora, fairly dense settlements of stromatoporata and some new elements among brachiopods and ostracodes. Thus, at the Wenlock-Ludlow boundary the distinct regressive succession is replaced by the succession with transgressive features. However, the accepted position of the boundary emphasizes only a change in the trends in the facies succession and cannot imply a drastic replacement of the regressive sedimentation by transgressive. A gradual change in sedimentary conditions and no drastic change in the fauna at the boundary discussed do not allow us to attribute the change to a fast eustatic fluctuation in the level of the World Ocean. These variations could be caused by tectonic movements which led to major regional changes in paleogeography. 


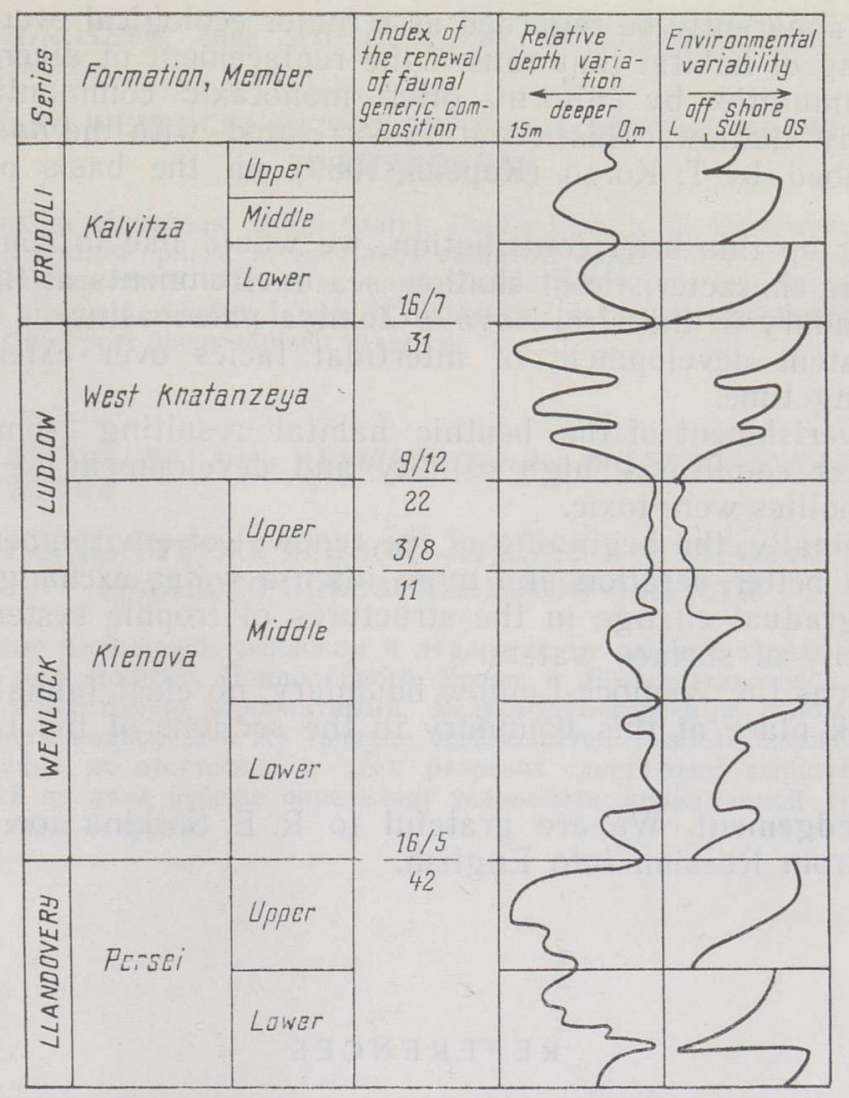

Fig. 3. Changes in sedimentary conditions of the Silurian southern Novaya Zemlya basin. $L$ - littoral area, $S U L$ - sublittoral area, $O S$ - open sea. In the numerator of the renewal index: first number - the number of new genera, second number - the number of surviving genera; in the denominator: the number of genera reaching a unit boundary.

The global scope of events at the Wenlock-Ludlow boundary is confirmed by data reported from other paleobasins. For example, the data of R. Einasto (Эйнасто, 1989) show the most extensive break marking probably the regression maximum to be related to the beginning of Ludlow in the Silurian succession of the Baltic paleobasin. According to D. Worsley et al. (1983) the early Silurian marine succession in some areas of the Oslo Region, Norway, is crowned by the appearance of red beds in lower Ringerike Group at the close of the Wenlock (nassa-ludensis zone). An interval transitional from Wenlock to Ludlow known as the Klinteberg Formation (Frikman, 1989) on Gotland Island in the Silurian section consisting of shallow water marine deposits shows characteristics of progressive shallowing at the close of the Wenlock and deepening in the beginning of the Ludlow. In Podolia the Wenlock-Ludlow boundary is marked by a drastic change in facies (Никифорова, Предтеченский, 1972).

The above examples imply that by the end of the Wenlock many shallow marine basins occupying vast areas had shallowed. This gave rise to changes in sedimentary conditions which, in turn, resulted in a considerable decrease in the diversity of late Wenlock benthic associations dominated by fairly uniform and mainly eurybiontic fauna. Therefore, the event which took place during the discussed time interval in shallow water basins of the Ural-Novaya Zemlya area and in similar basins in other 
regions can apparently be regarded as a major ecological event as it was the worsening of habitat that caused the replacement of diverse Wenlock benthic communities by uniform, often monotaxic communities of late Wenlock-early Ludlow. This event is correlated with the nassa-ludensis crisis described by T. Koren (Корень, 1989) on the basis of graptolite succession.

Summing up this brief contribution, we would like to concentrate on main features characteristic of shallow sea environments at the WenlockLudlow boundary in the Ural-Novaya Zemlya paleobasins.

1. Persistent development of intertidal facies over extensive areas during a long time.

2. Impoverishment of the benthic habitat resulting from extremely shallow water conditions, high salinity and development of algal mats whose metabolites were toxic.

3. And finally, the beginning of the renewal of environmental regime caused by a better aeration and more intense water exchange. This stimulated a gradual change in the structures of trophic systems and the bioproductivity of surface waters.

As concerns the Wenlock-Ludlow boundary, no clear faunal and facies changes took place at this boundary in the sections of the Ural-Novaya Zemlya area.

Acknowledgement. We are grateful to R. E. Sorkina for translating our report from Russian into English.

\section{REFERENCES}

Frikman, $P$. Carbonate ramp facies of the Klinteberg Formation, Wenlock-Ludlow transition on Gotland, Sweden. - Sver. Geol. Unders. C. 1989, N 820, 1-79.

Worsley, D., Aarhus, N., Bassett, M. G., Howe, P. A., Mork, A., Olaussen, S. The Silurian succession of the Oslo Region. - Norsk Geol. Unders., N 384, Bull. 72. Universitets forlaget. $1983,2-57$.

Абушик А. Ф. Силурийские остракоды Севера Евразии. Автореф. докт. дис. Ленинград, 1989.

Антошкина А. И., Безносова Т. М. Новые данные по стратиграфии венлокских отложений Большеземельской тундры. - Бюл. Моск. об-ва испыт. природы. Отд. геол., 1988, 63, вып. 6, 32-39.

Буко А. Эволюция и темпы вымирания. Москва, 1979.

Корень Т. Н. Основные событийные уровни граптолитовой последовательности силура. - In: Геология и палеонтология. Ленинград, 1989, 71-82.

Модзалевская T. Л. Некоторые вопросы стратиграфии силурийских отложений Большеземельской тундры. - Ежегодник ВПО, 22. Ленинград, 1980, 299-304.

Никифорова О. И., Предтеченский Н.Н. и др. Опорный разрез силура и нижнего девона Подолии. Ленинград, 1972.

Объяснительная записка к схеме стратиграфии верхнесилурийских отложений Вайгачско-Южноновоземельского региона. Ленинград, 1981.

Объяснительная записка к схеме стратиграфии нижнесилурийских отложений юга Новой Земли. Ленинград, 1983.

Опорные разрезы верхнего ордовика и нижнего силура Приполярного Урала. Сыктывкар, 1987

Периина А. И., Цыганко В. С., Щербаков Э. С., Боринцева Н. А. Биостратиграфия силурийских и девонских отложений Печорского Урала. Ленинград, 1971.

Силурийские и нижнедевонские отложения острова Долгого. Свердловск, 1980.

Эйнасто P. Э. Система перерывов в силуре Северной Прибалтики. - In: Геология и палеонтология. Ленинград, 1989, 142-153.

Presented by D. Kaljo

Received Nov, 20, 1990 


\section{SUNDMUSED WENLOCKI JA LUDLOW'PIIRIL UURALI-NOVAJA ZEMLJA PIIRKONNAS}

Novaja Zemlja lõunaosas, Dolgi saarel, Polaar-Uuralis ja Bolšezemelskaja tundras on Wenlocki ja Ludlow' piirikihid esindatud valdavalt karbonaatkivimitega, mis on kujunenud väga madalas meres. Nimetatud piiril täheldatakse nõrka basseini arengutendentsi muutust, kuid pisavalt selgete fauna ja faatsieste erinevuste puudumine ei võimalda alam- ja ülemsiluri piiri ühemōtteliselt määrata.

Людмила НЕХОРОШЕВА, Анна АБУШИК, Татьяна МОДЗАЛЕВСКАЯ, Дмитрий ПАТРУНОВ

\section{СОБЫТИЯ НА РУБЕЖЕ ВЕНЛОК-ЛУДЛОВ В ПАЛЕОБАССЕИНАХ УРАЛЬСКО-НОВОЗЕМЕЛЬСКОЙ ОБЛАСТИ}

Пограничные слои между венлоком и лудловом, по данным опорных разрезов юга Новой Земли, о-ва Долгого, Приполярного Урала и Большеземельской тундры, представлены преимущественно карбонатными, мелководно-морскими отложениями с признаками крайнего мелководья. На границе наблюдается слабое изменение тенденций развития бассейна, но отсутствие в этих разрезах достаточно выразительной смены фауны и фаций на этом рубеже определяет условность принимаемой границы между нижним и верхним силуром. 